\title{
Characteristics of effective self-management interventions in patients with COPD: individual patient data meta-analysis
}

\author{
Nini H. Jonkman ${ }^{1}$, Heleen Westland ${ }^{1}$, Jaap C.A. Trappenburg ${ }^{1}$, \\ Rolf H.H. Groenwold ${ }^{2}$, Erik W.M.A. Bischoff ${ }^{3}$, Jean Bourbeau ${ }^{4}$, \\ Christine E. Bucknall ${ }^{5}$, David Coultas ${ }^{6}$, Tanja W. Effing ${ }^{7}$, Michael Epton ${ }^{8}$, \\ Frode Gallefoss ${ }^{9}$, Judith Garcia-Aymerich ${ }^{10,11,12}$, Suzanne M. Lloyd ${ }^{13}$, \\ Evelyn M. Monninkhof ${ }^{14}$, Huong Q. Nguyen ${ }^{15}$, Job van der Palen ${ }^{16,17}$, \\ Kathryn L. Rice ${ }^{18}$, Maria Sedeno ${ }^{4}$, Stephanie J.C. Taylor ${ }^{19}$, Thierry Troosters ${ }^{20}$, \\ Nicholas A. Zwar ${ }^{21}$, Arno W. Hoes ${ }^{2}$ and Marieke J. Schuurmans ${ }^{1}$
}

ABSTRACT It is unknown whether heterogeneity in effects of self-management interventions in patients with chronic obstructive pulmonary disease (COPD) can be explained by differences in programme characteristics. This study aimed to identify which characteristics of COPD self-management interventions are most effective.

Systematic search in electronic databases identified randomised trials on self-management interventions conducted between 1985 and 2013. Individual patient data were requested for meta-analysis by generalised mixed effects models.

14 randomised trials were included (67\% of eligible), representing 3282 patients (75\% of eligible). Univariable analyses showed favourable effects on some outcomes for more planned contacts and longer duration of interventions, interventions with peer contact, without log keeping, without problem solving, and without support allocation. After adjusting for other programme characteristics in multivariable analyses, only the effects of duration on all-cause hospitalisation remained. Each month increase in intervention duration reduced risk of all-cause hospitalisation (time to event hazard ratios 0.98, 95\% CI 0.97-0.99; risk ratio (RR) after 6 months follow-up 0.96, 95\% CI 0.92-0.99; RR after 12 months follow-up $0.98,95 \%$ CI $0.96-1.00)$.

Our results showed that longer duration of self-management interventions conferred a reduction in all-cause hospitalisations in COPD patients. Other characteristics are not consistently associated with differential effects of self-management interventions across clinically relevant outcomes.

@ERSpublications

Increasing duration of self-management interventions reduces risk of all-cause hospitalisations in patients with COPD http://ow.ly/YVw9E

Editorial comment in: Eur Respir J 2016; 48: 6-9.

This article has supplementary material available from erj.ersjournals.com

Received: Nov 092015 | Accepted after revision: Feb 162016 | First published online: April 282016

Conflict of interests: Disclosures can be found alongside this article at erj.ersjournals.com

The content of this work is not subject to copyright. Design and branding are copyright @ERS 2016. 
Affiliations: ${ }^{1}$ Dept of Rehabilitation, Nursing Science and Sports, University Medical Center Utrecht, Utrecht, The Netherlands. ${ }^{2}$ Julius Center for Health Sciences and Primary Care, University Medical Center Utrecht, Utrecht, The Netherlands. ${ }^{3}$ Dept of Primary and Community Care, Radboud University Medical Center, Nijmegen, The Netherlands. ${ }^{4}$ Respiratory Epidemiology and Clinical Research Unit, Dept of Medicine, McGill University Health Center, McGill University, Montreal, Canada. ${ }^{5}$ Dept of Respiratory Medicine, Glasgow Royal Infirmary, Glasgow, UK. 'Veterans Administration Portland Health Care System and Oregon Health \& Science University, Portland, OR, USA. ${ }^{7}$ Dept of Respiratory Medicine, Repatriation General Hospital, Adelaide, Australia. ${ }^{8}$ Canterbury District Health Board, Respiratory Services, Christchurch Hospital, Christchurch, New Zealand. ${ }^{9}$ Dept of Pulmonary Medicine, Sorlandet Hospital, Kristiansand, Norway. ${ }^{10}$ Centre for Research in Environmental Epidemiology (CREAL), Barcelona, Spain. ${ }^{11}$ Universitat Pompeu Fabra (UPF), Barcelona, Spain. ${ }^{12}$ CIBER Epidemiología y Salud Pública (CIBERESP). Barcelona, Spain. ${ }^{13}$ Robertson Centre for Biostatistics, University of Glasgow, Glasgow, UK. ${ }^{14}$ Julius Center for Health Sciences and Primary Care, University Medical Center Utrecht, Utrecht, The Netherlands. ${ }^{15}$ Dept of Research and Evaluation, Kaiser Permanente Southern California, Pasadena, CA, USA. ${ }^{16}$ Dept of Research Methodology, Measurement and Data Analysis, University of Twente, Enschede, The Netherlands. ${ }^{17}$ Department of Clinical Epidemiology, Medisch Spectrum Twente, Enschede, The Netherlands. ${ }^{18}$ Division of Pulmonary, Allergy, Critical Care and Sleep Medicine, Minneapolis Veterans Affairs Health Care Service and University of Minnesota, Minneapolis, USA. ${ }^{19}$ Centre for Primary Care and Public Health, Queen Mary University of London, London, UK. ${ }^{20}$ Dept of Rehabilitation Sciences, Catholic University of Leuven, Leuven, Belgium. ${ }^{21}$ School of Public Health and Community Medicine, UNSW Australia, Sydney, Australia.

Correspondence: Nini H. Jonkman, Department of Rehabilitation, Nursing Science \& Sports, HP W01.121, University Medical Center Utrecht, Heidelberglaan 100, 3508 GA, Utrecht, The Netherlands.

E-mail: n.jonkmandumcutrecht.nl

\section{Introduction}

Chronic obstructive pulmonary disease (COPD) is a serious health problem, as it is one of the major causes of death worldwide [1] and negatively impacts patients' health status [2]. To counteract deterioration, patients with COPD are encouraged to adjust their lifestyle, monitor signs and symptoms, and adhere to complex medication regimes [2]. Interventions to improve these self-management behaviours have received considerable attention over recent years [3], as randomised trials showed beneficial effects on various outcomes, including health-related quality of life (HRQoL), dyspnoea, and healthcare utilisation [4]. However, new questions regarding the effectiveness of self-management interventions have emerged, since several recent randomised trials have shown inconclusive results $[5,6]$, or even deleterious effects [7].

The heterogeneous results of available trials can at least partly be attributed to the diversity of self-management interventions being evaluated. Although most self-management interventions involve an action plan to stimulate patients to anticipate on exacerbations [4] and several interventions [5-9] are based on the programme "Living Well with COPD" [8], the actual interventions vary widely in terms of intensity, duration, delivery, and content. Knowledge of which programme characteristics constitute the effective ingredients of self-management interventions might lead to the optimum design of this type of intervention.

A meta-analysis comparing the effectiveness of different self-management interventions could be a first step to provide evidence on which programme characteristics yield beneficial effects. The most recent Cochrane review on self-management interventions in patients with COPD attempted to identify effective programme characteristics, but this study was largely unrevealing due to little variation in the programme-specific determinants that were analysed [4]. Another recent systematic review on interventions containing self-management support for COPD patients found that from all included multicomponent interventions, those involving structured exercise or enhanced professional care were associated with better outcomes [10]. In this review, interventions with those specific characteristics were compared to usual care. A comprehensive analysis, in which treatment effects of interventions with and without specific characteristics are compared directly, is however needed to enable the identification of effective characteristics of self-management interventions.

An individual patient data (IPD) meta-analysis is the best tool for such an analysis. It enables a uniform statistical analysis and imputation of missing values across studies, while uncertainties (e.g. information on programme characteristics) can be checked with principal investigators [11]. Our IPD meta-analysis aimed to identify programme characteristics of self-management interventions in patients with COPD that affect HRQoL, all-cause and respiratory-related hospitalisation, and mortality.

\section{Methods}

Data sources and study selection

This study was conducted as part of a larger project on self-management interventions in patients with different chronic conditions for which the study protocol has been published [12].To identify randomised trials on self-management interventions in patients with COPD, the electronic databases of PubMed, 
EMBASE, CENTRAL, PsycINFO and CINAHL were searched from January 1985 through until June 2013 (search syntax can be found in table S1 in the online supplementary material). We also searched reference lists of any identified systematic reviews and consulted experts to avoid omission of available trials.

Studies were screened on title/abstract by one researcher (N.H. Jonkman). The full text of potentially eligible studies were retrieved and assessed by two independent researchers (N.H. Jonkman and H. Westland). Any discrepancies were resolved through consensus in presence of a third researcher (J.C.A. Trappenburg). This IPD meta-analysis only included studies on self-management interventions. Given that current views highlight the multifaceted nature of self-management interventions $[3,13]$, these were defined as interventions providing information to patients and including minimally two of the following components: 1) stimulation of sign/symptom monitoring; 2) education in problem solving skills, i.e. self-treatment of acute exacerbations and stress/symptom management; 3) smoking cessation; and stimulation of 4) medical treatment adherence; 5) physical activity; or 6) improving dietary intake. The general approach for each component had to be on enhancing the patient's active role and responsibility. Therefore, interventions focussing on pulmonary rehabilitation or tele-monitoring devices with passive surveillance were not considered eligible.

Studies were included in the IPD meta-analysis if they: 1) met the definition of self-management intervention above; 2) had a randomised trial design; 3) included patients with an established diagnosis of COPD according to the prevailing guidelines [2]; 4) compared the self-management intervention to usual care or another self-management approach; 5) reported data on one or more of the selected outcomes; 6) followed patients for at least 6 months; and 7) were reported in English, Dutch, French, German, Italian, Portuguese, or Spanish. No additional criteria were applied to exclude individual patients from the IPD meta-analysis.

Methodological quality was assessed by two researchers independently (N.H. Jonkman and H. Westland) using three relevant criteria from the Cochrane "Risk of bias" tool [14]: 1) random concealed treatment allocation; 2) intention-to-treat analysis; and 3) absence of other major sources of bias, e.g. high drop-out and risk of contamination. Discrepancies were solved through consensus with a third researcher (J.C.A. Trappenburg).

\section{Data collection}

Principal investigators of selected studies were invited to participate in this IPD meta-analysis and share their de-identified original trial data. A complete list of all requested variables and details on collaboration with principal investigators can be found in the protocol [14]. Data from each trial were checked and questions that arose were discussed and resolved with principal investigators.

\section{Outcomes}

To identify effective programme characteristics of self-management interventions across different health outcomes measured at the patient level, this study could only address outcomes collected in a uniform way across trials in COPD patients: HRQoL at 6- and 12-month follow-ups (measured with the Chronic Respiratory Questionnaire [15] or the St. George's Respiratory Questionnaire [16]), all-cause hospitalisation (time to first event, 6 months, and 12 months), respiratory-related hospitalisation (time to first event, 6 months, and 12 months), and mortality (time to event, 6 months, and 12 months).

\section{Programme characteristics}

Potential determinants of effective self-management interventions were selected prior to data analysis based on self-management and behaviour change literature and presence of programme characteristics across included studies: 1) Intensity (planned contacts, n) [17], 2) Duration of the intervention (months) [17], 3) Training given to interventionist(s) who delivers intervention to patients (standardised/heterogeneous) [18], 4) Type of interventionist(s) (multidisciplinary team/single interventionist) [19], 5) Contact with peer patients (yes/no) [20]. 6) Self-monitoring through keeping logs (yes/no) [21], 7) Goal-setting skills (yes/no) $[20], 8)$ Problem-solving skills (yes/no) [20], 9) Skills for seeking support in social network or from healthcare professionals (yes/no) [20], 10) Easy telephone access to case manager (yes/no) [22], and 11) Action plan including prescription for emergency treatment (yes/no) [23].

Information on programme characteristics was extracted for intervention and control arms from published manuscripts and trial protocols by two independent researchers (N.H. Jonkman and H. Westland), and checked with the principal investigators of the specific studies.

\section{Data analysis}

Data from individual studies were merged to create one database. Missing values were assumed to be missing at random (overall $2.7 \%$ missing data, except $33.7 \%$ for HRQoL follow-up data). Using multiple imputation by chained equations (25 imputations) [24], missing values for baseline variables and 
outcomes of individual patients were imputed within studies only. The imputed datasets were used for the primary analysis and the results were pooled using Rubin's rules [25].

All analyses were performed according to the intention-to-treat principle. Studies were analysed using a one-stage approach, i.e. simultaneously analysing all observations while accounting for clustering of observations within studies [26]. The continuous outcomes (HRQoL at 6 and 12 months) were quantified by standardised mean differences (SMD) between intervention and control arms and were analysed using linear mixed effects models. Binary outcome data (all-cause, respiratory-related hospitalisation, and mortality at 6 and 12 months) were analysed with log-binomial mixed effects models, which estimated risk ratios (RRs). All mixed effects models included a random intercept and random slope for the treatment effect per study. For time-to-event endpoints, effects of self-management were quantified by estimating hazard ratios (HRs) using Cox proportional-hazard models including a frailty term per study.

As an intermediary step in the analysis, we estimated the main effects of self-management interventions, i.e. without focusing on specific programme characteristics. Main effects have been reported elsewhere [27], but are presented to enable a comparison of the effects of specific programme characteristics with overall effects of self-management. The primary analysis comprised identification of effective programme characteristics of self-management interventions. Characteristics were evaluated one-by-one in separate analyses. Four trials had multiple intervention arms [5, 28-30], which were included as separate interventions. To identify the effect of intensity and duration of interventions, the aforementioned models were repeated with the covariate for treatment allocation (and random slope) being replaced by either intensity or duration of interventions.

For analysis of binary programme characteristics, studies were grouped according to the presence or absence of the characteristic and regression models were then fitted in both sets of studies separately. Differences between the two estimated effects from the sets of studies were tested on significance of effect modification across trials using a Q-test for heterogeneity [31], which was considered statistically significant if $\mathrm{p}<0.05$. Only statistically significant findings from the primary analysis are presented for a direct comparison across different endpoints.

The univariable approach did not allow adjustment for other programme characteristics, which may introduce confounding by other programme characteristics. For example, interventions including goal-setting skills might have had a longer duration than interventions without goal-setting skills. A multivariable analysis simultaneously estimating the effects of all programme characteristics overcomes this problem. Random slopes for each programme characteristic must be included to preserve the randomisation in individual trials and avoid confounding by patient characteristics. However, the number of included studies $(\mathrm{N}=14)$ was too small to perform this analysis. To check for confounding by other programme characteristics in the primary analysis, we performed a secondary analysis using only fixed effect regression models for the multivariable analysis. The regression models included all programme-specific covariates and a dummy variable indicating study. Additionally, the models were adjusted for sex, age, and forced expiratory volume in $1 \mathrm{~s}(\mathrm{FEV} 1)$ as a percentage of predicted of individual patients to adjust for baseline differences. Effect sizes and $95 \%$ confidence interval were estimated to compare these with observed effects from the primary analysis.

Several sensitivity analyses were performed to assess robustness of findings from the primary univariable analysis. Main effects were pooled with published main effects of eligible studies that could not provide original data to assess the impact of missing those studies. A complete-case analysis was performed to assess the impact of imputing data and the analyses were repeated by excluding the largest trial [9]. All analyses were performed in $\mathrm{R}$ for Windows version 3.1.1 (R Foundation for Statistical Computing, R Development Core Team, Vienna, Austria).

\section{Results}

21 studies met the inclusion criteria and principle investigators were approached to participate in this IPD meta-analysis (figure 1). 14 principal investigators responded positively and shared their non-identifiable trial data. Investigators of three studies could not be contacted, for two studies no approval from the local Institutional Review Board was given, the investigators of one study were not willing to participate, and data from another study were no longer available. Patients, programmes, and outcomes of eligible studies that could not provide original data were comparable to those of included studies (tables S2-S4).

Baseline characteristics of 3282 included patients ( $75 \%$ of eligible patients) are presented in table 1 . The majority of the patients were male $(65.6 \%)$. Patients had a mean \pm SD age of $68.1 \pm 9.6$ years and FEV1 of $18.9 \pm 47.7 \%$ pred. Only dyspnoea classification showed an imbalance between intervention arms, with $62.6 \%$ of the control patients classified as experiencing a high level of breathlessness at baseline compared to $49.8 \%$ of the intervention patients. 


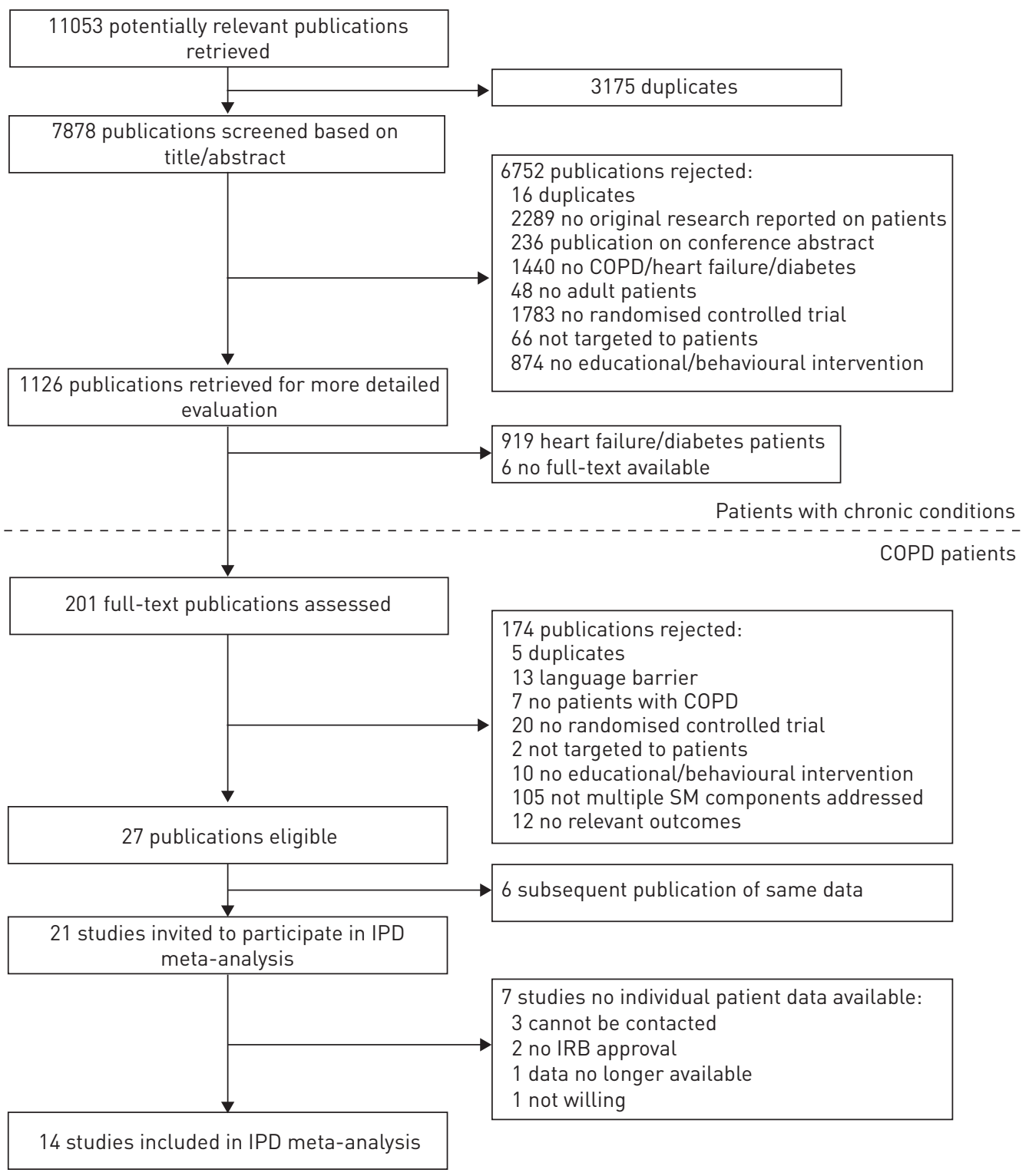

FIGURE 1 Flowchart of study selection for individual patient data meta-analysis. The present study was conducted as part of a larger project including patients with other chronic conditions li.e. patients with heart failure or type 2 diabetes mellitus). COPD: chronic obstructive pulmonary disease; SM: self-management; IPD: individual patient data; IRB: institutional review board.

\section{Description of studies and interventions}

Included studies have been reported previously and are presented in table 2. Studies were conducted between 1994 and 2008 in the Netherlands [5, 29, 36, 38], USA [9, 28, 30], UK [6, 37], Australia [39], Canada [8], New Zealand [35], Norway [34], and Belgium/Spain [33]. Most studies recruited clinically stable patients, experiencing at least one exacerbation in the previous year. Sample size ranged from 53 [34] to 743 patients [9]. Overall, methodological quality was good with few indications of high risk of bias (table S5). Interventions consisted on average of 10.5 planned contacts with healthcare professionals (range 1-35) and lasted on average 9.1 months (range 1 day-24 months). Extracted programme characteristics of each intervention arm are presented in table 3. The majority of interventions (15 out of 19) used a standardised protocol to train interventionists. Eight (42\%) interventions included a multidisciplinary team, nine $(47 \%)$ included peer contact, and in nine $(47 \%)$ logs were used for symptom monitoring. Goal-setting skills were taught in seven (37\%) interventions, problem-solving skills in 10 (53\%), and support seeking skills in nine (47\%). Patients had telephone access to a case manager in eight (42\%) interventions and were given an action plan with prescription for emergency medication in $11(58 \%)$ interventions. 


\begin{tabular}{|c|c|c|c|}
\hline Characteristic & Control & Intervention & Total \\
\hline Patients $\mathrm{n}$ & 1492 & 1790 & 3282 \\
\hline \multicolumn{4}{|l|}{ Sex } \\
\hline Male & $999(67.0)$ & $1151(64.3)$ & $2150(65.6)$ \\
\hline Female & $492(33.0)$ & $639(35.7)$ & $1131(34.5)$ \\
\hline Age & $68.3 \pm 9.6$ & $67.9 \pm 9.6$ & $68.1 \pm 9.6$ \\
\hline FEV $1 \%$ predicted & $47.3 \pm 18.8$ & $48.0 \pm 18.9$ & $47.7 \pm 18.9$ \\
\hline \multicolumn{4}{|l|}{ Dyspnoea" } \\
\hline Low level of breathlessness & $151(37.4)$ & $275(50.2)$ & $426(44.7)$ \\
\hline High level of breathlessness & $253(62.6)$ & $273(49.8)$ & $526(55.3)$ \\
\hline \multicolumn{4}{|l|}{ Level of education } \\
\hline Primary education or below & $313(39.6)$ & 391 (38.3) & 704 (38.9) \\
\hline Secondary education & $351(44.4)$ & $456(44.7)$ & $807(44.6)$ \\
\hline Higher education & $127(16.1)$ & $173(17.0)$ & $300(16.6)$ \\
\hline \multicolumn{4}{|l|}{ Smoking status } \\
\hline Current nonsmoker & $1036(71.8)$ & $1225(71.1)$ & $2261(71.4)$ \\
\hline Current smoker & $407(28.2)$ & $499(28.9)$ & $906(28.6)$ \\
\hline
\end{tabular}

Data are presented as $\mathrm{n}(\%)$ or mean $\pm \mathrm{SD}$. FEV1: forced expiratory volume in $1 \mathrm{~s} .{ }^{*}$ : based on score (modified) Medical Research Council (MRC) dyspnoea scale [31] and categorised according to Global Initiative for Chronic Obstructive Lung Disease guidelines [2], MRC $\geqslant 3$ or $m M R C \geqslant 2$ indicates high level of breathlessness.

\section{Primary analysis programme characteristics}

No single programme characteristic was effective on all outcomes considered, but several characteristics showed an effect on one or more outcomes (table 4). The intensity of interventions showed a risk reduction of all-cause hospitalisation for each increasing contact (time to first event HR 0.99, 95\% CI 0.98-1.00; at 6 months RR 0.98, 95\% CI 0.96-1.00; and at 12 months RR 0.98, 95\% CI 0.97-1.00). Similarly, each increasing month of duration of intervention reduced the risk of all-cause hospitalisation (time to first event HR 0.98, 95\% CI 0.97-0.99; at 6 months RR 0.96, 95\% CI 0.92-0.99 and at 12 months RR 0.98, 95\% CI 0.96-1.00). Interventions with peer contact reduced risk of respiratory-related hospitalisation at 6 months (RR $0.64,95 \%$ CI $0.45-0.92$ ), while there was no effect in the interventions without peer contact ( $R R$ 1.02, 95\% CI 0.76-1.38; interaction $\mathrm{p}=0.049$ ). The interventions using logs for symptom monitoring, irrespective of an action plan, showed no effect on time to first respiratory-related hospitalisation (HR 0.99, 95\% CI 0.77-1.28), while the interventions not using logs showed a risk reduction (HR 0.64, 95\% CI 0.50-0.82; interaction $\mathrm{p}=0.015$ ). In the analyses of mortality (time to death), all interventions teaching problem-solving skills also taught support seeking skills, resulting in similar subsets of studies. Those interventions showed a (nonsignificant) increased risk of death (HR 1.39, 95\% CI 0.91-2.11), which was not present in the interventions without those characteristics (HR 0.73, 95\% CI 0.48-1.11; interaction $\mathrm{p}=0.033$ ).

\section{Secondary analysis and sensitivity analysis}

The secondary multivariable analysis confirmed the reduced risks of all-cause hospitalisation with increasing duration of intervention (table 5), but the reduced risk for increased intervention intensity on all-cause hospitalisation disappeared when correcting for other programme characteristics (time to first event HR 1.08, 95\% CI 1.02-1.14; at 6 months RR 1.26, 95\% CI 0.57-2.80; and at 12 months: RR 1.00, 95\% CI 0.61-1.64). The increased risk of time to first respiratory-related hospitalisation for interventions including log keeping compared to those without log keeping in the primary analysis was not confirmed either as this became protective (HR 0.47, 95\% CI 0.26-0.83). Due to the low number of cases of respiratory-related hospitalisation at 6-month follow-up and time to death, those multivariable models were over-fitted and effects could not be estimated reliably. The sensitivity analyses showed effects in similar direction compared to the primary analysis (not reported).

\section{Discussion}

Self-management interventions in patients with COPD have shown positive overall effects on HRQoL, all-cause and respiratory-related hospitalisations, but there is considerable heterogeneity in outcomes [4]. To our knowledge, this is the first study using individual patient data aiming at identifying effective programme characteristics of self-management interventions for patients with COPD. The only consistent association observed was a favourable effect of longer duration of interventions on all-cause hospitalisation; 


\begin{tabular}{|c|c|c|c|c|c|c|c|c|c|c|}
\hline Author [ref] & Country & $\begin{array}{l}\text { Sample } \\
\text { size }\end{array}$ & $\begin{array}{l}\text { Recruitment } \\
\text { year }\end{array}$ & Setting & Patient population & Control group & Intervention group & $\begin{array}{c}\text { Duration of } \\
\text { intervention months }\end{array}$ & $\begin{array}{l}\text { Outcomes } \\
\text { collected }\end{array}$ & $\begin{array}{c}\text { Time-point } \\
\text { months }\end{array}$ \\
\hline BıschofF [5] & The Netherlands & 165 & 2004 & $\begin{array}{l}\text { General } \\
\text { practice }\end{array}$ & $\begin{array}{l}0.3 \leqslant \mathrm{FEV}_{1} / \mathrm{FVC} \\
<0.7, \text { no stability } \\
\text { criteria }\end{array}$ & $\begin{array}{l}\text { Usual care (contact } \\
\text { with general } \\
\text { practitioner) }\end{array}$ & $\begin{array}{l}\text { 1) } 2-4 \text { individual sessions by } \\
\text { nurse, action plan, follow-up } \\
6 \text { telephone calls } \\
\text { 2) } 2-4 \text { routine monitoring } \\
\text { sessions by nurse }\end{array}$ & 24 & HRQoL & 6,12 \\
\hline BouRbeAu [8] & Canada & 191 & 1998 & $\begin{array}{l}\text { Clinic/ } \\
\text { hospital }\end{array}$ & $\begin{array}{c}0.25<\mathrm{FEV}_{1} \% \text { pred } \\
<0.7, \geqslant 1 \\
\text { exacerbation in } \\
\text { last year }\end{array}$ & $\begin{array}{l}\text { Usual care (contact } \\
\text { with general } \\
\text { practitioner or } \\
\text { specialist, access to } \\
\text { provincial health } \\
\text { programme) }\end{array}$ & $\begin{array}{l}7 \text { individual sessions by } \\
\text { nurse/respiratory therapist/ } \\
\text { physiotherapist, } 1 \text { physical } \\
\text { exercise session, workbook, } \\
\text { action plan, follow-up } \\
\text { monthly telephone calls }\end{array}$ & 12 & $\begin{array}{c}\mathrm{HRQoL}, \\
\text { hospitalisations } \\
\text { (AC and respiratory } \\
\text { related) }\end{array}$ & 12 \\
\hline BucKNALL [6] & UK & 464 & 2007 & $\begin{array}{l}\text { Clinic/ } \\
\text { hospital }\end{array}$ & $\begin{array}{l}\mathrm{FEV}_{1} / \mathrm{FVC}<0.7 \text {, } \\
\text { post-exacerbation } \\
\text { hospitalisation }\end{array}$ & $\begin{array}{l}\text { Usual care lcontact } \\
\text { with general } \\
\text { practitioner, } \\
\text { specialists or both, } \\
\text { access to } 24 \mathrm{~h} \\
\text { helpline) }\end{array}$ & $\begin{array}{c}4 \text { individual home visits by } \\
\text { nurse, action plan, follow-up } \\
\text { by home visits at least every } \\
6 \text { weeks }\end{array}$ & 12 & $\begin{array}{c}\text { HRQoL, } \\
\text { hospitalisations } \\
\text { (AC and respiratory } \\
\text { related), mortality }\end{array}$ & 6,12 \\
\hline CASAS [33] & Belgium/Spain & 155 & 2005 & $\begin{array}{l}\text { Clinic/ } \\
\text { hospital }\end{array}$ & $\begin{array}{l}\text { Confirmed COPD, } \\
\text { post-exacerbation } \\
\text { hospitalisation }\end{array}$ & $\begin{array}{l}\text { Usual care (contact } \\
\text { with general } \\
\text { practitioner) }\end{array}$ & $\begin{array}{c}1 \text { individual session, } \\
\text { minimally } 1 \text { home visit by } \\
\text { nurse/physician, action plan, } \\
\text { follow-up } 4 \text { telephone calls }\end{array}$ & 1 & $\begin{array}{l}\text { HRQoL, } \\
\text { hospitalisations } \\
\text { (respiratory } \\
\text { related), mortality }\end{array}$ & 6,12 \\
\hline Coultas [28] & USA & 217 & 2000 & $\begin{array}{l}\text { General } \\
\text { practice }\end{array}$ & $\begin{array}{c}\mathrm{FEV}_{1} / \mathrm{FVC}<0.7 \text {, no } \\
\text { stability criteria }\end{array}$ & $\begin{array}{l}\text { Enhanced usual care } \\
\text { (two additional } \\
\text { educational booklets } \\
\text { for COPD) }\end{array}$ & $\begin{array}{l}\text { 1) } 1 \text { individual session by } \\
\text { nurse, follow-up } 6 \text { telephone } \\
\text { calls } \\
\text { 2) } 1 \text { individual session by } \\
\text { nurse, follow-up } 7 \text { telephone } \\
\text { calls }\end{array}$ & 6 & $\begin{array}{c}\text { HRQoL, } \\
\text { hospitalisations } \\
\text { (AC and respiratory } \\
\text { related), mortality }\end{array}$ & 6 \\
\hline Effing [29] & The Netherlands & 153 & 2004 & $\begin{array}{l}\text { Clinic/ } \\
\text { hospital }\end{array}$ & $\begin{array}{c}0.25 \leqslant F^{0} V_{1} \% \text { pred } \\
<0.8, \text { stable for } \\
\geqslant 1 \text { month }\end{array}$ & $\begin{array}{l}\text { Enhanced usual care } \\
\text { ( } 4 \text { group sessions on } \\
\text { self-management, } \\
\text { booklet on } \\
\text { self-management, } \\
\text { access to helpline) }\end{array}$ & $\begin{array}{l}\text { 1) } 4 \text { group sessions by } \\
\text { nurse/physiotherapist, } \\
\text { action plan, physical training } \\
\text { for } 11 \text { months, follow-up } \\
3 \text { telephone calls } \\
\text { 2) } 4 \text { group sessions by } \\
\text { nurse/ physiotherapist, } \\
\text { action plan, follow-up } \\
3 \text { telephone calls } \\
\text { 3) } 4 \text { group sessions by } \\
\text { nurse/ physiotherapist, } \\
\text { physical training for } \\
11 \text { months }\end{array}$ & 12 & $\begin{array}{l}\text { HRQoL, } \\
\text { hospitalisations } \\
\text { (respiratory } \\
\text { related), mortality }\end{array}$ & 6,12 \\
\hline Gallefoss [34] & Norway & 53 & 1994 & $\begin{array}{l}\text { Clinic/ } \\
\text { hospital }\end{array}$ & $\begin{array}{l}0.4 \leqslant \mathrm{FEV}_{1} \% \text { pred } \\
<0.8, \text { no stability } \\
\text { criteria }\end{array}$ & $\begin{array}{l}\text { Usual care (contact } \\
\text { with general } \\
\text { practitioner) }\end{array}$ & $\begin{array}{l}2 \text { group sessions, minimally } \\
2 \text { individual sessions by } \\
\text { multidisciplinary team, } \\
\text { action plan }\end{array}$ & 0.5 & $\begin{array}{l}\text { Hospitalisations } \\
\text { (respiratory } \\
\text { related) }\end{array}$ & 12 \\
\hline
\end{tabular}




\begin{tabular}{|c|c|c|c|c|c|c|c|c|c|c|}
\hline Author [ref] & Country & $\begin{array}{l}\text { Sample } \\
\text { size }\end{array}$ & $\begin{array}{l}\text { Recruitment } \\
\text { year }\end{array}$ & Setting & Patient population & Control group & Intervention group & $\begin{array}{c}\text { Duration of } \\
\text { intervention months }\end{array}$ & $\begin{array}{l}\text { Outcomes } \\
\text { collected }\end{array}$ & $\begin{array}{l}\text { Time-point } \\
\text { months }\end{array}$ \\
\hline McGеосн [35] & New-Zealand & 161 & 2002 & $\begin{array}{l}\text { General } \\
\text { practice }\end{array}$ & $\begin{array}{c}\mathrm{FEV}_{1} / \mathrm{FVC}<0.7, \geqslant 1 \\
\text { exacerbation in } \\
\text { last year }\end{array}$ & $\begin{array}{l}\text { Usual care (contact } \\
\text { with general } \\
\text { practitioner, not } \\
\text { standardised } \\
\text { education by } \\
\text { practices, access to } \\
\text { action plan denied) }\end{array}$ & $\begin{array}{l}1 \text { individual session by } \\
\text { nurse, action plan }\end{array}$ & 1 day & $\begin{array}{c}\text { HRQoL, } \\
\text { Hospitalisations } \\
\text { (AC and respiratory } \\
\text { related), mortality }\end{array}$ & 6,12 \\
\hline MoNNINKHOF [36] & The Netherlands & 248 & 1999 & $\begin{array}{l}\text { Clinic/ } \\
\text { hospital }\end{array}$ & $\begin{array}{c}0.25 \leqslant \mathrm{FEV}_{1} \% \text { pred } \\
<0.8, \text { stable for } \\
\geqslant 1 \text { month }\end{array}$ & $\begin{array}{l}\text { Enhanced usual care } \\
\text { (contact with general } \\
\text { practitioner, } \\
\text { smoking cessation } \\
\text { programme, } \\
\text { inhalation } \\
\text { instructions, access } \\
\text { to helpline) }\end{array}$ & $\begin{array}{c}5 \text { group sessions by nurse/ } \\
\text { physiotherapist, action plan, } \\
\text { physical training } \\
\text { programme for } 2 \text { years }\end{array}$ & 4 & $\begin{array}{c}\text { HRQoL, } \\
\text { hospitalisations } \\
\text { (respiratory } \\
\text { related), mortality }\end{array}$ & 6,12 \\
\hline Nguyen [30] & USA & 125 & 2007 & Combination & $\begin{array}{l}\mathrm{FEV}_{1} / \mathrm{FVC}<0.7 \\
\text { stable for } \\
\geqslant 1 \text { month }\end{array}$ & $\begin{array}{l}\text { Enhanced usual care } \\
\text { (home visit, monthly } \\
\text { group sessions on } \\
\text { general health } \\
\text { education, biweekly } \\
\text { telephone calls) }\end{array}$ & $\begin{array}{l}\text { 1) } 1 \text { home visit, } 6 \text { group } \\
\text { sessions by nurse, } \\
\text { educational booklet, } \\
\text { follow-up biweekly } \\
\text { telephone calls } \\
\text { 2) } 1 \text { home visit, } 6 \text { text chat } \\
\text { sessions with nurse, digital } \\
\text { learning modules, follow-up } \\
\text { biweekly e-mails }\end{array}$ & 12 & HRQoL & 6,12 \\
\hline RICE [9] & USA & 743 & 2004 & $\begin{array}{l}\text { Clinic/ } \\
\text { hospital }\end{array}$ & $\begin{array}{l}\text { Confirmed COPD, } \\
\geqslant 1 \text { exacerbation in } \\
\quad \text { last year }\end{array}$ & $\begin{array}{c}\text { Usual care } \\
\text { (including a } \\
\text { hand-out on COPD } \\
\text { and access to } 24 \mathrm{~h} \\
\text { helpline) }\end{array}$ & $\begin{array}{c}1 \text { group session by } \\
\text { respiratory therapist, } \\
\text { individualised action plan, } \\
\text { follow-up monthly telephone } \\
\text { calls }\end{array}$ & 12 & $\begin{array}{c}\text { HRQoL, } \\
\text { hospitalisations } \\
\text { (AC and respiratory } \\
\text { related), mortality }\end{array}$ & 6,12 \\
\hline TAYLOR [37] & UK & 116 & 2007 & $\begin{array}{l}\text { General } \\
\text { practice }\end{array}$ & $\begin{array}{l}\mathrm{FEV} 1<0.8 \% \text { pred, } \\
\geqslant 1 \text { exacerbation in } \\
\text { last year }\end{array}$ & $\begin{array}{l}\text { Usual care (not } \\
\text { standardised, } \\
\text { contact with general } \\
\text { practitioner or } \\
\text { specialists) }\end{array}$ & $\begin{array}{l}7 \text { group sessions by lay peer } \\
\text { tutor, action plan }\end{array}$ & 1.6 & $\begin{array}{c}\text { HRQoL, } \\
\text { hospitalisations } \\
\text { (respiratory } \\
\text { related), mortality }\end{array}$ & 6 \\
\hline TRAPPEN-BURG [38] & The Netherlands & 233 & 2008 & Combi-nation & $\begin{array}{l}\mathrm{FEV}_{1} / \mathrm{FVC}<0.7, \text { no } \\
\text { stability criteria }\end{array}$ & $\begin{array}{l}\text { Usual care (not } \\
\text { standardised, } \\
\text { contact with } \\
\text { respiratory nurse } \\
\text { and general } \\
\text { practitioner, possible } \\
\text { referral to } \\
\text { physiotherapist/ } \\
\text { dietician) }\end{array}$ & $\begin{array}{l}1 \text { individual session by } \\
\text { nurse, action plan, } \\
\text { follow-up } 2 \text { telephone calls }\end{array}$ & 4 & $\begin{array}{c}\text { HRQoL, } \\
\text { hospitalisations } \\
\text { (respiratory } \\
\text { related), mortality }\end{array}$ & 6 \\
\hline ZWAR [39] & Australia & 258 & 2002 & $\begin{array}{l}\text { General } \\
\text { practice }\end{array}$ & $\begin{array}{c}\mathrm{FEV} 1 / \mathrm{FVC}<0.7 \\
\geqslant 1 \text { exacerbation in } \\
\quad \text { last year }\end{array}$ & $\begin{array}{l}\text { Usual care (contact } \\
\text { with general } \\
\text { practitioner, written } \\
\text { COPD guidelines) }\end{array}$ & $\begin{array}{c}2 \text { home visits by nurse, } \\
2 \text { visits to physician, action } \\
\text { plan, follow-up } 5 \text { telephone } \\
\text { calls }\end{array}$ & 6 & $\begin{array}{c}\text { HRQoL, } \\
\text { hospitalisations } \\
\text { (AC and respiratory } \\
\text { related), mortality }\end{array}$ & 6,12 \\
\hline
\end{tabular}


TABLE 3 Programme characteristics of the self-management interventions in patients with chronic obstructed pulmonary disease included in the individual patient data meta-analysis

\begin{tabular}{|c|c|c|c|c|c|c|c|c|c|c|}
\hline Author [ref] & $\begin{array}{c}\text { Recruitment } \\
\text { year }\end{array}$ & $\begin{array}{l}\text { Standardised } \\
\text { training }\end{array}$ & $\begin{array}{l}\text { Multidisciplinary } \\
\text { team }\end{array}$ & $\begin{array}{l}\text { Peer } \\
\text { contact }\end{array}$ & $\begin{array}{l}\text { Logs } \\
\text { kept }\end{array}$ & $\begin{array}{l}\text { Goals } \\
\text { set }\end{array}$ & $\begin{array}{c}\text { Problem } \\
\text { solving }\end{array}$ & $\begin{array}{l}\text { Support } \\
\text { allocation }\end{array}$ & $\begin{array}{l}\text { Easy telephone } \\
\text { access }\end{array}$ & $\begin{array}{c}\text { Action plan } \\
\text { with prescription }\end{array}$ \\
\hline Galleffos [34] & 1994 & + & + & + & + & & & & & + \\
\hline BouRBEAU [8] & 1998 & + & + & & & & + & & + & + \\
\hline MoNNINKHOF [36] & 1999 & + & + & + & + & & + & + & + & + \\
\hline Coultas [28] & 2000 & + & & & & & & & & \\
\hline Coultas [28] & 2000 & + & & & & & & & & \\
\hline McGEOCH [35] & 2002 & + & & & & & & & & + \\
\hline BischofF [5] & 2004 & + & & & & & + & & + & + \\
\hline BıschofF [5] & 2004 & & & & & & & & & \\
\hline EFFING [29] & 2004 & + & + & + & + & + & + & + & + & + \\
\hline Effing [29] & 2004 & + & + & + & + & + & + & + & + & + \\
\hline Effing [29] & 2004 & + & + & + & + & + & & + & & \\
\hline RICE [9] & 2004 & + & & + & & & & & + & + \\
\hline CASAS [33] & 2005 & + & + & & & & + & + & + & + \\
\hline ZWAR [39] & 2006 & + & + & & & + & & & & + \\
\hline BuckNALL [6] & 2007 & + & & & + & & + & + & + & + \\
\hline NGUYen [30] & 2007 & & & + & + & + & + & + & & \\
\hline Nguyen [30] & 2007 & & & + & + & + & + & + & & \\
\hline TAYLOR [37] & 2007 & + & & + & & + & + & + & & \\
\hline TRAPPENBURG [38] & 2008 & & & & + & & & & & \\
\hline Totals $\#$ & & 15 & 8 & 9 & 9 & 7 & 10 & 9 & 8 & 11 \\
\hline
\end{tabular}

+: characteristic present in intervention. ${ }^{\#}$ : interventions $\mathrm{N}=19$ 
TABLE 4 Primary analysis of effects of self-management interventions and characteristics in patients with chronic obstructive pulmonary disease included in the individual patient data meta-analysis

\begin{tabular}{|c|c|c|c|c|c|c|c|c|}
\hline Outcome & Studies & $\begin{array}{l}\text { Events/patients } \\
\text { control }\end{array}$ & $\begin{array}{l}\text { Events/patients } \\
\text { intervention }\end{array}$ & Analysis & $\begin{array}{c}\text { Effect } \\
\text { measured }\end{array}$ & Effect & p-value ${ }^{\#}$ & $I^{2} \%$ \\
\hline \multicolumn{9}{|c|}{ Health-related quality of life } \\
\hline 6 months & 9 & 811 & 1065 & $\begin{array}{l}\text { Intervention effect } \\
\text { No significant components }\end{array}$ & SMD & $0.05(-0.05-0.15)$ & & 0.0 \\
\hline 12 months & 10 & 1233 & 1431 & $\begin{array}{l}\text { Intervention effect } \\
\text { No significant components }\end{array}$ & SMD & $0.08(0.00-0.16)$ & & 0.0 \\
\hline \multicolumn{9}{|c|}{ All-cause hospitalisation } \\
\hline \multirow[t]{3}{*}{ Time to first event } & 4 & $381 / 773$ & $334 / 786$ & Intervention effect & \multirow[t]{3}{*}{ HR } & $0.80(0.69-0.93)$ & & \multirow[t]{3}{*}{51.0} \\
\hline & 4 & $381 / 773$ & $334 / 786$ & Intensity (per contact) & & $0.99(0.98-1.00)$ & 0.007 & \\
\hline & 4 & $381 / 773$ & $334 / 786$ & Duration (per month) & & $0.98(0.97-0.99)$ & 0.002 & \\
\hline \multirow[t]{3}{*}{6 months } & 6 & $282 / 959$ & $256 / 1075$ & Intervention effect & \multirow[t]{3}{*}{$\mathrm{RR}$} & $0.81(0.67-0.97)$ & & \multirow[t]{3}{*}{47.8} \\
\hline & 6 & 282/959 & $256 / 1075$ & Intensity (per contact) & & $0.98(0.96-1.00)$ & 0.013 & \\
\hline & 6 & $282 / 959$ & $256 / 1075$ & Duration (per month) & & $0.96(0.92-0.99)$ & 0.025 & \\
\hline \multirow[t]{3}{*}{12 months } & 5 & $398 / 886$ & $351 / 931$ & Intervention effect & \multirow[t]{3}{*}{$\mathrm{RR}$} & $0.84(0.73-0.96)$ & & \multirow[t]{3}{*}{44.3} \\
\hline & 5 & $398 / 886$ & $351 / 931$ & Intensity (per contact) & & $0.98(0.97-1.00)$ & 0.013 & \\
\hline & 5 & $398 / 886$ & $351 / 931$ & Duration (per month) & & $0.98(0.96-1.00)$ & 0.012 & \\
\hline \multicolumn{9}{|c|}{ Respiratory-related hospitalisation } \\
\hline \multirow[t]{3}{*}{ Time to first event } & 6 & $276 / 928$ & $218 / 944$ & Intervention effect & \multirow[t]{3}{*}{$\mathrm{HR}$} & $0.79(0.66-0.94)$ & & \multirow[t]{3}{*}{20.6} \\
\hline & 2 & $119 / 354$ & $115 / 343$ & Keeping logs & & $0.99(0.77-1.28)$ & 0.015 & \\
\hline & 4 & $157 / 574$ & $103 / 601$ & Not keeping logs & & $0.64(0.50-0.82)$ & & \\
\hline \multirow[t]{3}{*}{6 months } & 8 & $200 / 1114$ & $173 / 1233$ & Intervention effect & \multirow[t]{3}{*}{$\mathrm{RR}$} & $0.87(0.69-1.09)$ & & \multirow[t]{3}{*}{0.0} \\
\hline & 2 & $65 / 409$ & $46 / 450$ & Peer contact & & $0.64(0.45-0.92)$ & 0.049 & \\
\hline & 6 & $135 / 705$ & $127 / 783$ & No peer contact & & $1.02(0.76-1.38)$ & & \\
\hline 12 months & 9 & $347 / 1163$ & $268 / 1263$ & $\begin{array}{c}\text { Intervention effect } \\
\text { No significant components }\end{array}$ & $\mathrm{RR}$ & $0.77(0.64-0.93)$ & & 0.0 \\
\hline \multicolumn{9}{|c|}{ 新 } \\
\hline \multirow[t]{3}{*}{ Time to event } & 7 & $91 / 1049$ & $91 / 1071$ & Intervention effect & \multirow[t]{3}{*}{$\mathrm{HR}$} & $1.02(0.76-1.37)$ & & \multirow[t]{3}{*}{0.0} \\
\hline & 4 & $39 / 481$ & $52 / 502$ & $\begin{array}{l}\text { Problem solving/ } \\
\text { support skills }\end{array}$ & & $1.39(0.91-2.11)$ & 0.033 & \\
\hline & 3 & $52 / 568$ & $39 / 569$ & $\begin{array}{l}\text { No problem-solving/ } \\
\text { support skills }\end{array}$ & & $0.73(0.48-1.11)$ & & \\
\hline 6 months & 9 & $52 / 1161$ & $54 / 1329$ & $\begin{array}{c}\text { Intervention effect } \\
\text { No significant components }\end{array}$ & $\mathrm{RR}$ & $1.06(0.62-1.82)$ & & 0.0 \\
\hline 12 months & 7 & $95 / 1041$ & $94 / 1141$ & $\begin{array}{l}\text { Intervention effect } \\
\text { No significant components }\end{array}$ & $\mathrm{RR}$ & $1.04(0.64-1.69)$ & & 0.0 \\
\hline
\end{tabular}

Data are presented as $n, n / n$ or effect $(95 \% \mathrm{Cl})$, unless otherwise stated. Results are only presented if a programme characteristic showed an effect with $\mathrm{p}<0.05$ in the primary analysis. $\mathrm{Cl}$ : confidence interval, HR: hazard ratio, RR: risk ratio, SMD: standardised mean difference. ${ }^{\#}$ : $p$-value for Q-test for heterogeneity to test for modification of effect by the programme characteristic. 
TABLE 5 Secondary analysis of effects of programme characteristics in patients with chronic obstructive pulmonary disease included in the individual patient data meta-analysis adjusted for other characteristics

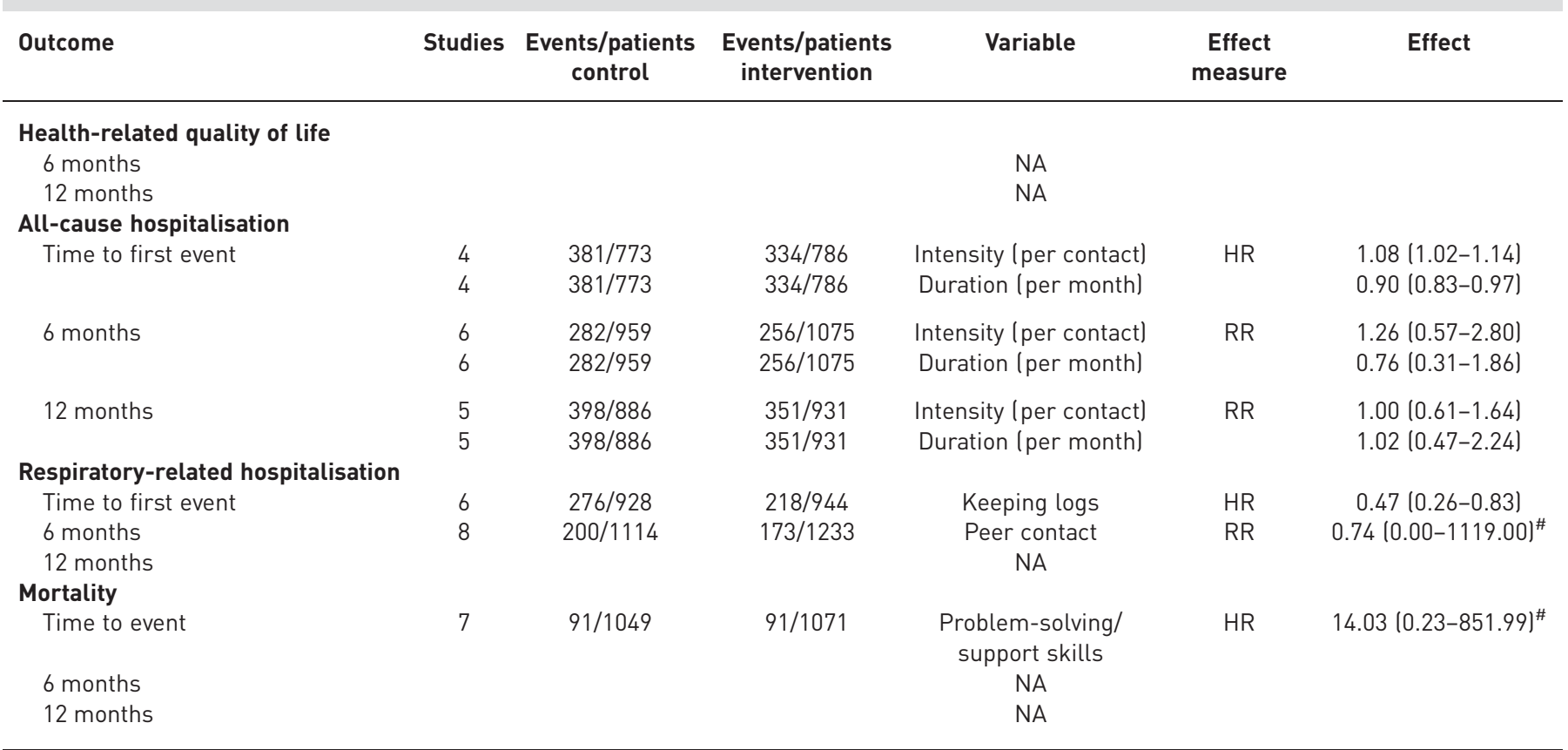

Data are presented as $\mathrm{n}, \mathrm{n} / \mathrm{n}$ or effect $(95 \% \mathrm{Cl})$, unless otherwise stated. Results are only presented if a programme characteristic showed an effect with $\mathrm{p}<0.05$ in the primary analysis. $\mathrm{Cl}$ : confidence interval; NA: not available; HR: hazard ratio; RR: risk ratio. ${ }^{\#}$ : over fitted model due to low number of cases, no interpretation possible.

for each increasing month of the intervention there was a $2 \%$ risk reduction on time to first event, $4 \%$ risk reduction on 6 -month hospitalisation, and $2 \%$ risk reduction on 12 -month hospitalisation. Effects observed in univariable analysis for intensity of interventions, peer contact, log keeping, and problem-solving/ support allocation could not be confirmed when corrected for other programme characteristics.

The association between self-management programme characteristics and outcomes in patients with COPD have been evaluated previously in two reviews, but both used summary data across included trials instead of data at the level of individual patients [4, 10]. One review pooled data from 174 trials that included a self-management component [10]. Multicomponent interventions and those with structured exercise or enhanced professional care did better when compared to usual care [10]. The results of this review are not comparable with our results, since the authors applied rather wide inclusion criteria and the study selection contained many pulmonary rehabilitation interventions with (very) limited self-management components. The authors of the other review pre-specified different programme characteristics for their analysis, including duration of follow-up $\geqslant 12$ months [4]. Due to limited variation across the 23 included trials, no analyses could be undertaken on this characteristic [4] and the other analyses were largely unrevealing. Considering their findings, we chose to analyse the duration of interventions continuously, which revealed small favourable effects on all-cause hospitalisation. The beneficial effect of longer-lasting interventions may extend beyond the COPD population, since there is evidence that longer duration of behavioural interventions is associated with maintenance of behaviour change in the general population [40] and better clinical outcomes in patients with heart failure [41].

Longer-lasting interventions in our selection of studies generally consisted of an intensive start, followed by regular contacts with the patient over a defined period of time. This may have provided more opportunities to prompt and discuss feedback regarding patients' behaviour. Although our results suggest that longer-lasting self-management strategies should be recommended for clinical practice rather than brief interventions, we still lack knowledge on the minimum required duration or dosing and associated costs. Recently published 2-year follow-up data from one of the trials included in our study [29] demonstrated a fading out of the 1-year effect on exercise capacity while the effect on activity level was maintained [42]. This implies that self-management interventions suffer from at least some attrition of treatment effects once the intervention is terminated and that sustained contact with patients is needed.

Our findings might also indicate that the observed effects of self-management interventions are strongly attributable to regular professional review and less to content. A study on self-management support in diabetes 
care showed that contacts of professionals with patients mainly improved biomedical monitoring instead of self-management behaviours [43]. Those findings support prior research revealing the difficulties professionals experience with implementing self-management interventions in practice $[44,45]$. This emphasises that we should pay considerable attention to supporting professionals to change their own behaviour in approaching patients, to ensure that patients receive the self-management intervention as intended. Self-management interventions take time and continuous support to achieve better patient outcomes.

This IPD meta-analysis was the first study using original trial data of 3282 patients to identify effective characteristics of self-management interventions. This enabled a uniform statistical analysis and close collaboration with principal investigators ensured correct labelling of programme characteristics. Although we performed careful data collection and analysis, we only revealed a clear association for duration of interventions with all-cause hospitalisation. Several programme characteristics that seemed to modify the effect in the univariable analysis, disappeared as effect modifiers after adjustment for co-occurrence of other programme characteristics in multivariable models. Therefore, the counterintuitive negative effects observed in univariable analysis for log keeping, problem-solving skills, and support seeking skills may be attributable to another common characteristic of those studies. Potential explanations for not finding other pronounced effective programme characteristics might be related to methodological limitations of conducting an IPD meta-analysis on multicomponent self-management interventions. First, although individual patient data were used, programme characteristics were analysed on the level of complete studies, like a classic meta-analysis. The low number of included studies $(\mathrm{N}=14)$ limited the possibility of analysing programme characteristics in a multivariable mixed effects model and interpreting findings causally. However, we applied a secondary fixed effect analysis to assess whether univariable effects could be confirmed after adjustment.

Another explanation may be that some of the included studies actually failed to intervene, i.e. the intervention was not properly implemented or was not delivered to all the intervention patients. Data on the actual delivery of the intervention by the interventionist (fidelity of intervention delivery) and the adherence to the intervention by patients were requested but not collected by authors in a majority of the trials. Therefore, an additional on-treatment analysis to assess whether these phenomena played a role could not be performed. Insight into the delivery and uptake of self-management interventions through (mixed method) process evaluations alongside trials is essential as this can increase our understanding of how different programme characteristics contribute [46].

Third, the analysis required a simplification of the different programme characteristics through categorisation. This may have created large, still heterogeneous groups of studies being compared (i.e. peer contact in one study may have differed from that in another study), a problem more often encountered in meta-regression analyses [47]. Detailed, uniform reporting of different programme characteristics of interventions in future trials may facilitate a better comparison of interventions, for example, through the use of existing taxonomies [48].

Fourth, the analyses were not adjusted for differences in the control groups across studies since these differed on too many aspects (e.g. setting, country, and year of inclusion). Studies were performed in various countries over a time frame of 14 years, which may have introduced additional variability [49]. It is possible that programme characteristics may be particularly effective in a specific healthcare context. It is also likely that some programme characteristics are only effective in subgroups of patients instead of the entire study population. Future research should address the hypothesis that subgroups of patients might respond differently to specific self-management interventions. Behaviour change evolves over time, with different patterns and timelines for different people. This knowledge can further guide the development of tailored self-management approaches.

Finally, according to self-management [20] and behaviour change literature [21], we focused in our analyses on clinically relevant programme characteristics related to mode, dose, and techniques for delivery of the self-management interventions. Although we analysed a rather large selection of potential determinants, this selection was limited to characteristics that varied between studies and it is possible that we have missed critical characteristics. Nevertheless, we performed multiple analyses, which increased the risk of false-positive findings, so the findings should be interpreted with caution.

\section{Conclusion}

Duration of self-management interventions is the only programme characteristic that could be identified in this IPD meta-analysis to modify the effect of self-management interventions in patients with COPD, increasing duration was associated with reductions in all-cause hospitalisations. This suggests that longer-lasting self-management strategies are recommended for clinical practice rather than brief interventions. This study further highlights the need for process evaluations alongside randomised trials, with special attention for monitoring intervention delivery. 


\section{References}

1 Lozano R, Naghavi M, Foreman K, et al. Global and regional mortality from 235 causes of death for 20 age groups in 1990 and 2010: a systematic analysis for the Global Burden of Disease Study 2010. Lancet 2012; 380: 2095-2128.

2 Global Initiative for Chronic Obstructive Lung Disease. Global Strategy for the Diagnosis, Management and Prevention of COPD-2016. www.goldcopd.org/guidelines-global-strategy-for-diagnosis-management.html Date last accessed: March 25, 2016. Date last updated: December, 2016.

3 Bourbeau J, van der Palen J. Promoting effective self-management programmes to improve COPD. Eur Respir J 2009; 33: 461-463.

4 Zwerink M, Brusse-Keizer M, van der Valk PD, et al. Self management for patients with chronic obstructive pulmonary disease. Cochrane Database Syst Rev 2014; 3: CD002990.

5 Bischoff EW, Akkermans R, Bourbeau J, et al. Comprehensive self management and routine monitoring in chronic obstructive pulmonary disease patients in general practice: randomised controlled trial. BMJ 2012; 345: e7642.

6 Bucknall CE, Miller G, Lloyd SM, et al. Glasgow supported self-management trial (GSuST) for patients with moderate to severe COPD: randomised controlled trial. BMJ 2012; 344: e1060.

7 Fan VS, Gaziano JM, Lew R, et al. A comprehensive care management program to prevent chronic obstructive pulmonary disease hospitalizations: a randomized, controlled trial. Ann Intern Med 2012; 156: 673-683.

8 Bourbeau J, Julien M, Maltais F, et al. Reduction of hospital utilization in patients with chronic obstructive pulmonary disease: a disease-specific self-management intervention. Arch Intern Med 2003; 163: 585-591.

9 Rice KL, Dewan N, Bloomfield HE, et al. Disease management program for chronic obstructive pulmonary disease: a randomized controlled trial. Am J Respir Crit Care Med 2010; 182: 890-896.

10 Jordan RE, Majothi S, Heneghan NR, et al. Supported self-management for patients with moderate to severe chronic obstructive pulmonary disease (COPD): an evidence synthesis and economic analysis. Health Technol Assess 2015; 19: 36.

11 Riley RD, Lambert PC, Abo-Zaid G. Meta-analysis of individual participant data: rationale, conduct, and reporting. BMJ 2010; 340: c221.

12 Higgins JPT, Green S. Cochrane Handbook for Systematic Reviews of Interventions, Version 5.1.0. London, The Cochrane Collaboration, 2011.

13 McGowan PT. Self-management education and support in chronic disease management. Prim Care 2012; 39: $307-325$.

14 Jonkman NH, Westland H, Trappenburg JC, et al. Towards tailoring of self-management for patients with chronic heart failure or chronic obstructive pulmonary disease: a protocol for an individual patient data meta-analysis. BMJ Open 2014; 4: e005220.

15 Guyatt GH, Berman LB, Townsend M, et al. A measure of quality of life for clinical trials in chronic lung disease. Thorax 1987; 42: 773-778.

16 Jones PW, Quirk FH, Baveystock CM, et al. A self-complete measure of health status for chronic airflow limitation. The St. George's Respiratory Questionnaire. Am Rev Respir Dis 1992; 145: 1321-1327.

17 Conn VS, Cooper PS, Ruppar TM, et al. Searching for the intervention in intervention research reports. J Nurs Scholarsh 2008; 40: 52-59.

18 Barlow J, Wright C, Sheasby J, et al. Self-management approaches for people with chronic conditions: a review. Patient Educ Couns 2002; 48: 177-187.

19 Sochalski J, Jaarsma T, Krumholz HM, et al. What works in chronic care management: the case of heart failure. Health Aff 2009; 28: 179-189.

20 Lorig KR, Holman H. Self-management education: history, definition, outcomes, and mechanisms. Ann Behav Med 2003; 26: 1-7

21 Michie S, Abraham C, Whittington C, et al. Effective techniques in healthy eating and physical activity interventions: a meta-regression. Health Psychol 2009; 28: 690-701.

22 Bourbeau J. Self-management interventions to improve outcomes in patients suffering from COPD. Expert Rev Pharmacoecon Outcomes Res 2004; 4: 71-77.

23 Walters JA, Turnock AC, Walters EH, et al. Action plans with limited patient education only for exacerbations of chronic obstructive pulmonary disease. Cochrane Database Syst Rev 2010; 5: CD005074.

24 Groothuis-Oudshoorn K, van Buuren S. Mice: multivariate imputation by chained equations in R. J Stat Softw 2011; 45: 1-67.

25 Rubin DB. Multiple imputation for non-response in surveys. New York, John Wiley \& Sons, 1987.

26 Stewart GB, Altman DG, Askie LM, et al. Statistical analysis of individual participant data meta-analyses: a comparison of methods and recommendations for practice. PLoS One 2012; 7: e46042.

27 Jonkman N, Westland H, Trappenburg J, et al. Who benefits most from COPD self-management interventions? An individual patient data meta-analysis. Eur Respir J 2015; 46: Suppl. 59, PA1809.

28 Coultas D, Frederick J, Barnett B, et al. A randomized trial of two types of nurse-assisted home care for patients with COPD. Chest 2005; 128: 2017-2024.

29 Effing T, Kerstjens H, van der Valk P, et al. (Cost)-effectiveness of self-treatment of exacerbations on the severity of exacerbations in patients with COPD: the COPE II study. Thorax 2009; 64: 956-962.

30 Nguyen HQ, Donesky D, Reinke LF, et al. Internet-based dyspnea self-management support for patients with chronic obstructive pulmonary disease. J Pain Symptom Manage 2013; 46: 43-55.

31 Borenstein M, Hedges LV, Higgins JPT, et al. Introduction to Meta-Analysis. Chichster, John Wiley \& Sons, 2009.

32 Bestall JC, Paul EA, Garrod R, et al. Usefulness of the Medical Research Council (MRC) dyspnoea scale as a measure of disability in patients with chronic obstructive pulmonary disease. Thorax 1999; 54: 581-586.

33 Casas A, Troosters T, Garcia-Aymerich J, et al. Integrated care prevents hospitalisations for exacerbations in COPD patients. Eur Respir J 2006; 28: 123-130.

34 Gallefoss F, Bakke PS, Kjaersgaard P. Quality of life assessment after patient education in a randomized controlled study on asthma and chronic obstructive pulmonary disease. Am J Respir Crit Care Med 1999; 159: 812-817.

35 McGeoch GR, Willsman KJ, Dowson CA, et al. Self-management plans in the primary care of patients with chronic obstructive pulmonary disease. Respirology 2006; 11: 611-618. 
36 Monninkhof E, van der Valk $\mathrm{P}$, van der Palen J, et al. Effects of a comprehensive self-management programme in patients with chronic obstructive pulmonary disease. Eur Respir J 2003; 22: 815-820.

37 Taylor SJC, Sohanpal R, Bremner SA, et al. Self-management support for moderate-to-severe chronic obstructive pulmonary disease: a pilot randomised controlled trial. Br J Gen Pract 2012; 62: e687-e695.

38 Trappenburg JC, Monninkhof EM, Bourbeau J, et al. Effect of an action plan with ongoing support by a case manager on exacerbation-related outcome in patients with COPD: a multicentre randomised controlled trial. Thorax 2011; 66: 977-984.

39 Zwar NA, Hermiz O, Comino E, et al. Care of patients with a diagnosis of chronic obstructive pulmonary disease: a cluster randomised controlled trial. Med J Aust 2012; 197: 394-398.

40 Fjeldsoe B, Neuhaus M, Winkler E, et al. Systematic review of maintenance of behavior change following physical activity and dietary interventions. Health Psychol 2011; 30: 99-109.

41 Göhler A, Januzzi JL, Worrell SS, et al. A systematic meta-analysis of the efficacy and heterogeneity of disease management programs in congestive heart failure. J Card Fail 2006; 12: 554-567.

42 Zwerink $\mathrm{M}$, van der Palen J, Kerstjens $\mathrm{HA}$, et al. A community-based exercise programme in COPD self-management: two years follow-up of the COPE-II study. Respir Med 2014; 108: 1481-1490.

43 Penn ML, Kennedy AP, Vassilev II, et al. Modelling self-management pathways for people with diabetes in primary care. BMC Fam Pract 2015; 16: 112.

44 Kennedy A, Bower P, Reeves D, et al. Implementation of self management support for long term conditions in routine primary care settings: cluster randomised controlled trial. BMJ 2013; 346: f2882.

45 Kennedy A, Rogers A, Bowen R, et al. Implementing, embedding and integrating self-management support tools for people with long-term conditions in primary care nursing: a qualitative study. Int J Nurs Stud 2014; 51: $1103-1113$

46 Moore GF, Audrey S, Barker M, et al. Process evaluation of complex interventions: Medical Research Council guidance. BMJ 2015; 350: h1258.

47 Warsi A, Wang PS, LaValley MP, et al. Self-management education programs in chronic disease: a systematic review and methodological critique of the literature. Arch Intern Med 2004; 164: 1641-1649.

48 Michie S, Richardson M, Johnston M, et al. The behavior change technique taxonomy (v1) of 93 hierarchically clustered techniques: building an international consensus for the reporting of behavior change interventions. Ann Behav Med 2013; 46: 81-95.

49 Peters GJ, de Bruin M, Crutzen R. Everything should be as simple as possible, but no simpler: towards a protocol for accumulating evidence regarding the active content of health behaviour change interventions. Health Psychol $\operatorname{Rev} 2015$; 9: 1-14. 